The International Conference : Cities' Identity Through Architecture and Arts (CITAA)

\title{
Guide to Maintain Historic Egyptian Mosques: Case Study of Abul-Hajjaj Mosque - Luxor
}

DOI: $10.21625 /$ archive.v1i1.108

Hesham Osman Abd Elrahman ${ }^{1}$

${ }^{1}$ Lecturer, Department of Architectural Engineering, Faculty of Engineering, Al Azhar University

\section{Keywords}

Guide; $\quad$ Maintenance; Historic ; Mosques ; Egypt.;

\begin{abstract}
The mosque is considered one of the most important buildings of the Islamic city since the Prophet's Mosque (peace and blessings be upon him), and maintenance is considered an important element and a cornerstone of buildings in general. This is due to the deterioration of public buildings generally given the bad use and common ownership of the mosque, in turn, its facilities are deteriorated. Some mosques belong to historic buildings, so maintaining them is of extra importance.

In light of the status of the construction and maintenance systems of historic mosques in Egypt and the limitations and problems faced, this paper presents a proposed guide for the preventive maintenance of historic mosques. It also provides clear evidence for workers in the field of maintenance of mosques including the key elements that need to be taken into consideration while preparing the preventive maintenance plan for mosques.
\end{abstract}

The preventive maintenance of the mosque needs a range of tools and methods in order to succeed. Planning and scheduling for items are major elements among these tools. In order to achieve integration between the elements and the different phases mentioned above, we need to formulate them in a form of an integrated guide with completed elements and dimensions. To find a guide for the maintenance of the mosques we should clearly identify the principles and rules for that guide, which comes through clarity of the purpose, the elements required to be controlled, how to control them, the statement of the time and places and the economic aspects of the guide.

This research aims to find a guide for the maintenance of historic mosques, by making a case study for the Mosque of Abul-Hajjaj in Luxor.

\section{Introduction}

Historic buildings are facing a problem with staying in line with the idea of reviving the ancient buildings through the re-run. The elements of a historic building are split to two main sections:

-Archaeological elements: any item older than 100 years, or belong to an era older than the current era, whether (single architecture, furniture, antiques, ... etc.).

The New elements: that have been added to the building to revive it (such as a single architecture, architectural supplements, or alarms or elements of modern finishing, ...etc). 


\section{Aim of the research}

The research aims to create a plan for preventive maintenance of historic mosques in line with modern elements and their life span to be drafted in executable timetable. This is important because any malfunction, failure or corruption of one of these elements significantly affects the archaeological mosque, which can lead to significant damage to the building and make it incompatible with the concept of revival, especially with religious uses of the mosque by the local community.

\section{Contents of this Research:}

- Preventive maintenance.

- historical study - case study.

- Develop a plan and maintenance program, according to a schedule.

\section{Preventive Maintenance:}

Preventive maintenance is working to maintain and protect buildings from being damaged to function fully as long as possible with the repair of defects in order to preserve it; and to reduce the expensive costs resulting from negligence or delay. These measures also include the participation of all the technical and administrative means, these actions include the preparation, planning and execution of the maintenance process as well as following up and monitoring during and after implementation.

Preventive maintenance is planned maintenance and is characterized as the prior identification of the elements of planning through a system of prior examination and tests to determine the status of each element of the building and maintenance work required.

Preventive maintenance is defined as "the organization plan for the repair and maintenance of the building in order to preserve the building components in operating its best and work to prolong their useful life", including activities aimed at preventing breakdowns, such as regular inspections and the replacement of some parts on the basis of a regular schedule. Where to prolong the life of the components of the buildings requires regular replacement of some of the different elements of the building such as electrical and plumbing elements, as preventive maintenance requires capital and operating expenses . (OFFICE OF THE LEGISLATIVE AUDITOR)

\section{Historical Study:}

The history of the establishment of the mosque to the Ayyubid period; the year $658 \mathrm{AH}$ (After emmigration of Muslims from Mekkah to Medina), $1286 \mathrm{AD}$, and is built on the northeast side of the Luxor Temple. The design of this mosque resembles the design of the small Fatimid mosques, such as the Esna Mosque in Aswan and AlMashhad el-Bahari on the bank of the Nile.

The mosque was built on a small square area and has a small dome. The entrance to the mosque is on the west side. It is well known that some changes were made to the mosque in the Ayyubid era. The mosque was built in the northeast area of Luxor Temple. It probably dates back to the middle of the Fatimid era.

The entrance of the mosque has three arches with heights of about 12 meters or 39 feet, covered with marble and faience. This was probably one of the changes that was made in the Ayyubid age as manifested by the artistic style.

Inside the mosque, there is a niche of simple design that is free of ornaments. There is also a small grave in which Yousef Ibn Abdel-Raheem, known as Abu Al-Haggag, was buried. On the top of the mosque, there is also a row of balconies that were built with baked bricks as it was restored in 1914 AD by Khedive Abbas Helmy the Second.

The slim minaret is located at the top of the northeast side of Luxor temple. Its height is about 14.15 meters or 46.41 feet and it was constructed on the thresholds above the four granite pillars in the temple, which form an invisible base. The minaret's base is set on those thresholds.

The base was constructed from adobes, or sun-dried bricks, was made square-shaped, and had a height of 6.85 meters or 22.47 feet. The base has three belts made of wood, slightly sloping to the inside as it goes upwards. The base has three openings for lighting and an arched entrance in the eastern corner. Four small domed pillars are located on the top of the four corners of the square-shaped base. There is also a sloping cylindrical body on the top of that base with a diameter of 2.58 meters or 8.46 feet at the bottom and 1.80 meters or 5.90 feet at the top, with its height at 7.66 meters or 25.12 feet.

Abul-Hajjaj Mosque 
Building Period: $\quad$ 1286AD - 658HD

Typology: Mosque

State of conservation: Fair

Recent Restoration: 2009AD

Accessed by Public: Yes
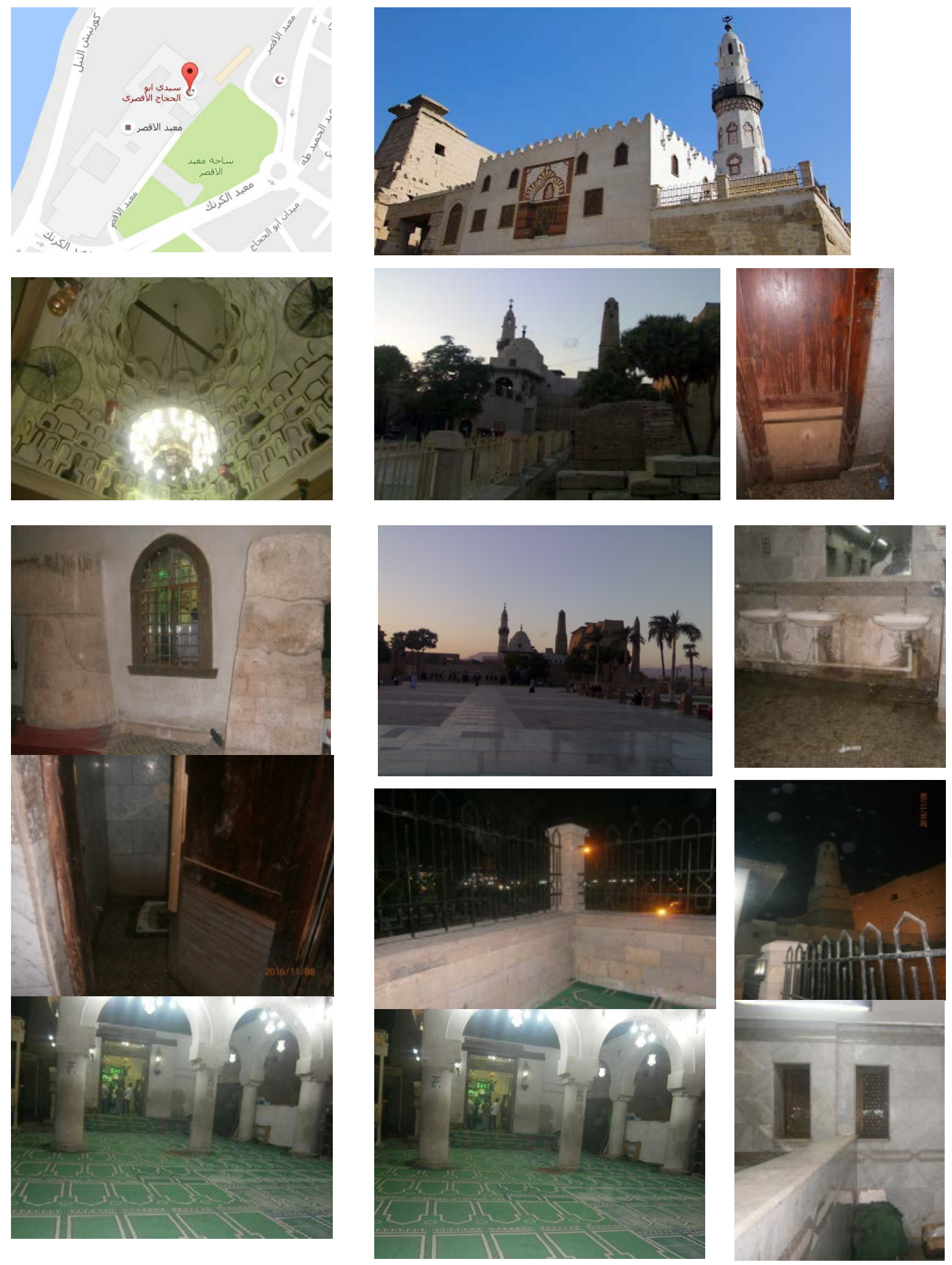

pg. 3 
Figure 1. Interior \& Exterior Pecture to the Mosque of Abul-Hajjaj in Luxor.

\section{Preventive Maintenance Guide for Historic Mosques:}

The followng are some of the steps that are integrated together to form a guide:

\subsection{Determine all the elements and components of historic mosques buildings:}

There are archaeological elements \& new elemnts in Table 1

Table 1.Archaeological elements \& new elemnts of historic mosques buildings

\begin{tabular}{|c|c|c|c|c|c|}
\hline No. & $\begin{array}{l}\text { The main } \\
\text { archaeological } \\
\text { element }\end{array}$ & The Sub-archaeological element & No. & $\begin{array}{l}\text { The main new } \\
\text { elements }\end{array}$ & $\begin{array}{l}\text { The sub- } \\
\text { element of the } \\
\text { new elements }\end{array}$ \\
\hline 1 & $\begin{array}{l}\text { The external } \\
\text { elements }\end{array}$ & Archaeological Fences & 1 & \multirow{4}{*}{$\begin{array}{l}\text { The yard and } \\
\text { external corridors }\end{array}$} & Flooring \\
\hline 2 & Infrastructure & Foundations & & & Metal gates \\
\hline \multirow[t]{7}{*}{3} & \multirow{7}{*}{$\begin{array}{l}\text { Architectural } \\
\text { elements }\end{array}$} & Exterior walls & & & Fences Metal \\
\hline & & Windows and exterior doors & & & Lighting units \\
\hline & & Roof & 2 & \multirow{4}{*}{$\begin{array}{l}\text { Sanitation and } \\
\text { Water supply }\end{array}$} & cold water \\
\hline & & Covers surfaces & & & hot water \\
\hline & & the stairs & & & Sewer lines \\
\hline & & Domes & & & $\begin{array}{l}\text { The external } \\
\text { sewage lines }\end{array}$ \\
\hline & & Minarets & 3 & \multirow{4}{*}{$\begin{array}{l}\text { Mechanical } \\
\text { Services } \\
\text { (Heating - Air - } \\
\text { gases) }\end{array}$} & HVAC \\
\hline \multirow[t]{3}{*}{4} & \multirow{3}{*}{ Internal structure } & Interior walls and partitions & & & Public utility \\
\hline & & Interior doors & & & Generators \\
\hline & & The walls of the shrine & & & $\begin{array}{l}\text { Electrical } \\
\text { transformers }\end{array}$ \\
\hline \multirow[t]{3}{*}{5} & \multirow{3}{*}{$\begin{array}{l}\text { Finishes and } \\
\text { fixtures }\end{array}$} & Ceilings finishing & 4 & \multirow{3}{*}{ various works } & $\begin{array}{c}\text { Simple } \\
\text { renovations }\end{array}$ \\
\hline & & Walls Finishing & & & \multirow{2}{*}{$\begin{array}{c}\text { General } \\
\text { cleanliness }\end{array}$} \\
\hline & & Wooden units surrounded the shrine & & & \\
\hline
\end{tabular}

By studying both of the main and sub elements, we found the elements and components of (Abu Hajjaj mosque), show in the table below. 
Table 2. elements and components of Abul-Hajjaj mosque

\begin{tabular}{|c|c|c|c|c|c|}
\hline No. & The main element & The Sub-element & No. & The main element & The sub-element \\
\hline 1 & $\begin{array}{l}\text { Archaeological } \\
\text { Fences }\end{array}$ & Metalworking & 10 & Lighting units & Fluorescent lamps \\
\hline 2 & $\begin{array}{l}\text { Windows and } \\
\text { exterior doors }\end{array}$ & Woodwork + Paints & 11 & $\begin{array}{l}\text { water supply } \\
\text { (cold -hot) }\end{array}$ & $\begin{array}{c}\text { Metal Pipes } \\
\text { (galvanized iron) + } \\
\text { Plastic pipes + pipes } \\
\text { polypropylene }\end{array}$ \\
\hline 3 & $\begin{array}{l}\text { the roof of } \\
\text { external yard }\end{array}$ & Metal Umbrellas & 12 & Sewer lines & $\begin{array}{c}\text { Pipes Pvc }+ \text { cast iron } \\
\text { pipes }\end{array}$ \\
\hline 4 & the stairs & Granite + metal handles & 13 & $\begin{array}{l}\text { The external } \\
\text { sewage lines }\end{array}$ & $\begin{array}{c}\text { Pipes Pvc }+ \text { cast iron } \\
\text { pipes }\end{array}$ \\
\hline 5 & Interior doors & Woodwork + Paints & 14 & HVAC & Fans \\
\hline 6 & $\begin{array}{l}\text { Wooden } \\
\text { surrounded } \\
\text { shrine }\end{array}$ & Woodwork + Paints & 15 & Bathrooms & wooden doors \\
\hline 7 & Flooring & Granite floors & 16 & Bathrooms & Toilet devices \\
\hline 8 & Metal fences & Metalworks + Paints & 17 & Bathrooms & Sinks \\
\hline 9 & Metal gates & Metalworks + Paints & 18 & Bathrooms & $\begin{array}{l}\text { Ceramic (walls\& } \\
\text { floors) }\end{array}$ \\
\hline
\end{tabular}

\subsection{Determine the Life Span for Elements and Components of Historic Mosques}

Through references which determine the approximate life span of the elements and components of the buildings, we can determine the life span of elements and components of the mosque, as illustrated in Table 3 .( A. c. Panchdhari 2007), ( NAHB, 2007), (Spirinckx Carolin \& others, 2011), (J. Breen, A. Boersma, 2005). 


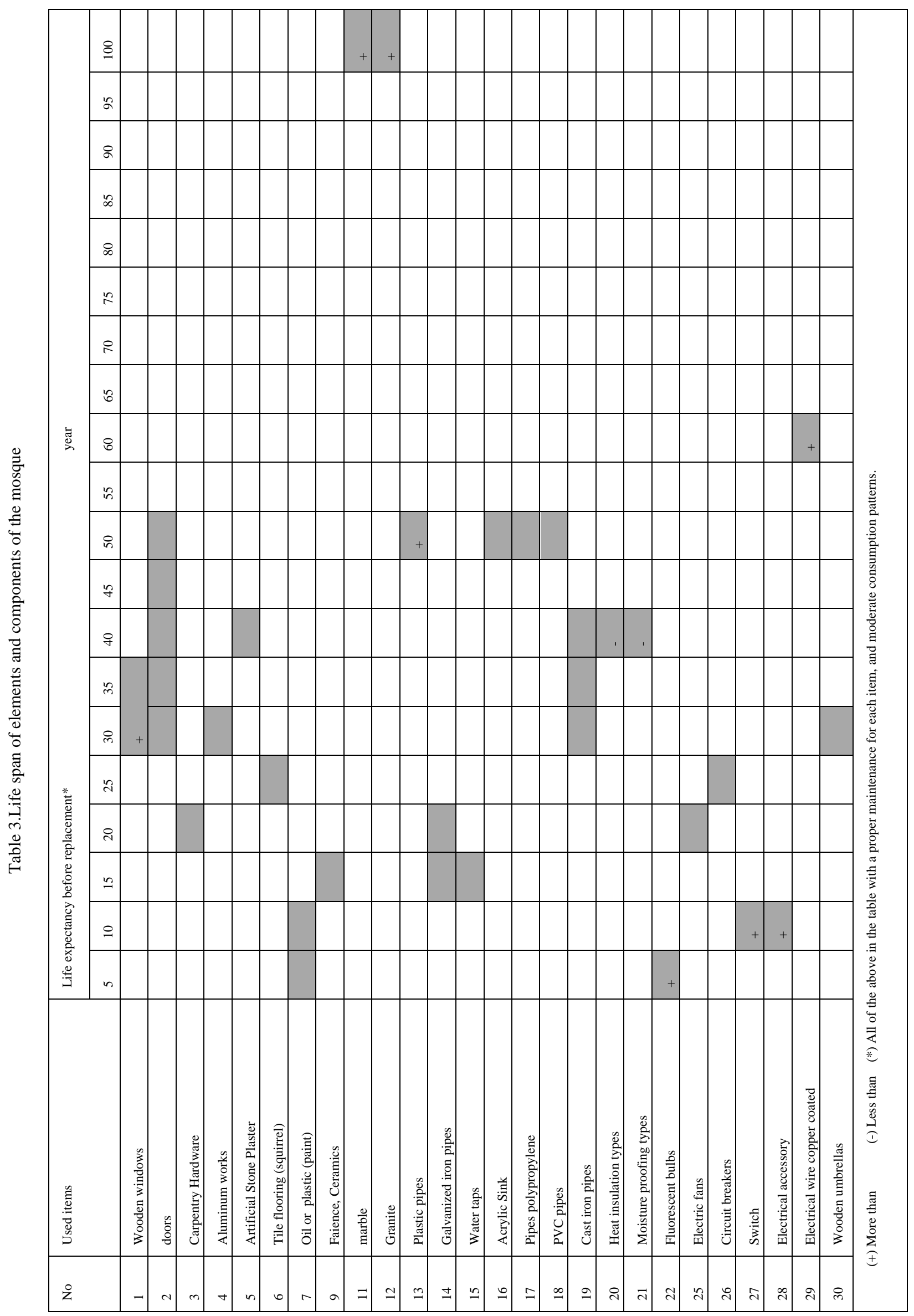




\subsection{Determining the Timetable for Maintenance:}

This stage includes determining the type, location and timing of inspections procedures as well as schedules for maintenance operations. This was carried out through the study of the history of building elements and by identifying the needs of periodic maintenance work depending on the age span of construction materials and finishing to these elements.

By studying the schedules of many tests for the maintenance of buildings in the world, table (4) shows some monitoring and periodic examination and maintenance operations of the components of historical mosques in Egypt activities.

Table 4.Some of regular inspection activities and maintenance operations of the components of historical mosques.

\begin{tabular}{|c|c|c|c|c|}
\hline $\begin{array}{l}\text { No } \\
\text {. }\end{array}$ & $\begin{array}{l}\text { Building } \\
\text { elements }\end{array}$ & Material & Monitoring and maintenance operations & $\begin{array}{l}\text { Inspectio } \\
\text { n time } \\
\text { periodic } \\
\text { year }\end{array}$ \\
\hline 1 & $\begin{array}{l}\text { External } \\
\text { and } \\
\text { internal } \\
\text { walls }\end{array}$ & Bricks & $\begin{array}{l}\text { - Inspection and rehabilitation of the surfaces of exterior walls } \\
\text { resulting from the various damages such as moisture. } \\
\text { - Inspection and rehabilitation of the surfaces of exterior walls at } \\
\text { the points of intersection with other materials, and searching for } \\
\text { any scratches on the outer surfaces with a follow-up to the final } \\
\text { surface condition. } \\
\text { - Determine if there are cracks in the walls and determine the } \\
\text { location and the nature, size and being a vertical or horizontal or } \\
\text { slanted. } \\
\text { - Determine if there are signs of moisture or leakage and } \\
\text { determine the location and size. } \\
\text { - Determine if there are any subsidence or cracks, faults in } \\
\text { sentiment, the loss of plaster or gypsum, any bows or cracks. }\end{array}$ & 2 \\
\hline 2 & $\begin{array}{l}\text { Internal } \\
\text { coatings }\end{array}$ & $\begin{array}{l}\text { Ceramic. } \\
\text { Porcelain }\end{array}$ & $\begin{array}{l}\text { - Control of the adhesion of tiles and cracks or peeling of the } \\
\text { cladding, any small works of restoration or replacement of the } \\
\text { livery }\end{array}$ & 1 \\
\hline 3 & $\underline{\text { Facade }}$ & $\begin{array}{l}\text { Stones } \\
\text { Cladding } \\
\text { Marble, } \\
\text { Granite }\end{array}$ & $\begin{array}{l}\text { - Monitor any signs of cracks or fall panels. } \\
\text { - Verification of the degree of gloss and the integrity of the } \\
\text { surface, and the presence of stains or dirt. } \\
\text { - Check the status of the surface, and connectors, spacers, } \\
\text { cleaning by pressure washing, } \\
\text { - Apply any preventive treatment, working to reconnect walls. }\end{array}$ & 5 \\
\hline 4 & Roofs & $\begin{array}{l}\text { Squirrel } \\
\text { tile } \\
\& \\
\text { Metal } \\
\text { gutters. }\end{array}$ & $\begin{array}{l}\text { - Collect and clean up and remove all the leaves and waste from } \\
\text { all roofs. } \\
\text { - Verification of the rain gutters on roofs. } \\
\text { - Ensure the protection elements of the roofs like stones or tiles. } \\
\text { - Achieve a minimum of paint to roof gutters by anti-water paints, } \\
\text { especially at places of twisting bends and pipes. } \\
\text { - Ensure moisture stains on ceilings, which indicate the presence } \\
\text { of leaks. } \\
\text { - Remove any leaves or garbage from the gutters and down pipes, } \\
\text { especially during the rainy season }\end{array}$ & 1 \\
\hline 5 & $\begin{array}{l}\text { External } \\
\text { and } \\
\text { internal } \\
\text { doors }\end{array}$ & $\begin{array}{l}\text { Wooden } \\
\text { doors }\end{array}$ & $\begin{array}{l}\text { - Ensure that the doors are closed properly and do not touch the } \\
\text { ground. } \\
\text { - Ensure the validity of door handles, locks and that they work } \\
\text { properly } \\
\text { - All doors are painted. } \\
\text { - Door and window frames cleaned every five years. } \\
\text { - Check the door and window Hardware's, cleaning and } \\
\text { lubrication. }\end{array}$ & 2 \\
\hline
\end{tabular}




\begin{tabular}{|l|l|l|l|l|}
\hline \multirow{2}{*}{6} & $\begin{array}{l}\text { External } \\
\text { paints }\end{array}$ & • Plastic & $\begin{array}{l}\text { • Re-paint the exterior walls, after washing the surfaces and work } \\
\text { to recover a minimum of putty }\end{array}$ & 10 \\
\cline { 2 - 6 } & $\begin{array}{l}\text { Interior } \\
\text { paints }\end{array}$ & & 5 & 5 \\
\hline
\end{tabular}

Table 5.Continued Some of regular inspection and maintenance operations of the components of historical mosques.

\begin{tabular}{|c|c|c|c|c|}
\hline No. & $\begin{array}{l}\text { Building } \\
\text { elements }\end{array}$ & Material & Monitoring and maintenance operations & $\begin{array}{l}\text { Inspection } \\
\text { time } \\
\text { periodic / } \\
\text { year }\end{array}$ \\
\hline \multirow[t]{2}{*}{7} & \multirow{2}{*}{$\begin{array}{l}\text { Metal } \\
\text { work }\end{array}$} & Iron fences & \multirow{2}{*}{$\begin{array}{l}\text { - Repainting the iron work in the most places susceptible to rust. } \\
\text { - Lubricate hinges. } \\
\text { • Lubrication, repair and / or replacement the locks and handles. } \\
\text { • Polishing artifacts brass. }\end{array}$} & 3 \\
\hline & & $\begin{array}{l}\text { Stairs, } \\
\text { window, } \\
\text { and gates } \\
\text { metals }\end{array}$ & & 2 \\
\hline 8 & windows & $\begin{array}{l}\text { Wood \& } \\
\text { glass }\end{array}$ & $\begin{array}{l}\text { - Ensure that all the windows open and close smoothly. } \\
\text { - Check the status of hardware (hinges, locks, etc.). } \\
\text { - All windows are painted. } \\
\text { - All glass panels are intact and there is no cracks or fractures }\end{array}$ & 2 \\
\hline \multirow[t]{2}{*}{9} & \multirow[t]{2}{*}{$\begin{array}{l}\text { External } \\
\text { floors }\end{array}$} & $\begin{array}{l}\text { External } \\
\text { sidewalks } \\
\& \\
\text { walkways }\end{array}$ & $\begin{array}{l}\text { - Inspections and restoration to tacks. } \\
\text { - Replace the floor panels are damaged. } \\
\text { - Ensure the tiles are not fractured or cracked. } \\
\text { - Replace or re-install any dislocated or broken tiles. }\end{array}$ & 2 \\
\hline & & $\begin{array}{l}\text { Ceramic, } \\
\text { Porcelain } \\
\text { Granite. } \\
\text { Marble. }\end{array}$ & $\begin{array}{l}\text { - Small works repair and fill the breaks. } \\
\text { - Repair or replacement of partial to the area's most prone to use } \\
\text { (by up to } 10 \% \text { of the flat). } \\
\text { • Control of the adhesion of tiles and cracks. }\end{array}$ & 1 \\
\hline \multirow[t]{3}{*}{10} & \multirow[t]{3}{*}{$\begin{array}{l}\text { Interior } \\
\text { floors }\end{array}$} & \multirow{2}{*}{$\begin{array}{l}\text { Ceramic. } \\
\text { Porcelain } \\
\text { Granite. } \\
\text { Marble. } \\
\text { Stone }\end{array}$} & \multirow{2}{*}{$\begin{array}{l}\text { - Small works repair and fill the breaks. } \\
\text { - Repair or replacement of partial to the area's most prone to use } \\
\text { (by up to } 10 \% \text { of the flat). } \\
\text { - Monitor the adhesion and cracks in floor tiles. } \\
\text { - Monitor any cracks in the edges of walls with the floor. }\end{array}$} & 1 \\
\hline & & & & 2 \\
\hline & & $\begin{array}{l}\text { Linoleum. } \\
\text { PVC } \\
\text { Rubber. } \\
\text { Carpet }\end{array}$ & $\begin{array}{l}\text { - Monitor irregular surface and any bulge or lift the edges. } \\
\text { - Check, clean and repair. }\end{array}$ & 1 \\
\hline 11 & $\begin{array}{l}\text { Ceilings } \\
\text { finishes }\end{array}$ & $\begin{array}{l}\text { Cement } \\
\text { plaster } \\
\text { stucco } \\
\text { plaster }\end{array}$ & $\begin{array}{l}\text { - Observe any swelling or any chromatic change in the ceilings. } \\
\text { • Loss of plaster or gypsum, any bends or cracks. }\end{array}$ & 5 \\
\hline 12 & $\begin{array}{l}\text { Wooden } \\
\text { umbrella } \\
\text { s }\end{array}$ & $\begin{array}{l}\text { Wooden } \\
\text { umbrellas } \\
\text { of different } \\
\text { types. }\end{array}$ & $\begin{array}{l}\text { - Checking all the connectivity elements and change them if } \\
\text { necessary, and verify of the stability of the umbrella. } \\
\text { - Check the integrity of wood panels and replace them if } \\
\text { necessary, re-painted if necessary. }\end{array}$ & 1 \\
\hline
\end{tabular}




\begin{tabular}{|c|l|l|l|l|}
\hline 13 & $\begin{array}{l}\text { Electrica } \\
1 \text { fixtures }\end{array}$ & $\begin{array}{l}\text { Electrical } \\
\text { appliances. } \\
\text { Lighting } \\
\text { units. }\end{array}$ & $\begin{array}{l}\bullet \text { Ensure that any pumps and electric motors are operating } \\
\text { properly. } \\
\bullet \text { Make sure the lighting equipment, fans, keys operating } \\
\text { properly. } \\
\bullet \text { Clean light fixtures and ceiling fans and change damaged. }\end{array}$ & 3 \\
\hline 14 & $\begin{array}{c}\text { Electrica } \\
\text { connecti } \\
\text { ons }\end{array}$ & $\begin{array}{l}\text { Connectors } \\
\text { insulators } \\
\text { Connectivi } \\
\text { ty Tools } \\
\text { Circuit } \\
\text { breakers } \\
\text { Switches } \\
\text { and fuses } \\
\text { Dielectrics }\end{array}$ & $\begin{array}{l}\text { prevent overheating. } \\
\bullet \text { Clean all the circuit breakers from dust. } \\
\bullet \text { Tighten the connections joints, checking connectors and } \\
\text { change the damaged ones. } \\
\bullet \text { Cleaning the circuit breakers, check the keys and make sure } \\
\text { not one of them is burning. } \\
\text {-Clean and sharpen fuses by the soft sand and change damaged } \\
\text { when necessary. } \\
\bullet \text { Insulation resistance measurement. }\end{array}$ & 3 \\
\hline
\end{tabular}

Table 6.Continued Some of regular inspection and maintenance operations of the components of historical mosques

\begin{tabular}{|c|c|c|c|c|}
\hline No. & $\begin{array}{l}\text { Building } \\
\text { elements }\end{array}$ & Material & Monitoring and maintenance operations & $\begin{array}{l}\text { Inspection } \\
\text { time } \\
\text { periodic / } \\
\text { year }\end{array}$ \\
\hline 15 & $\begin{array}{l}\text { Sanitary } \\
\text { Devices }\end{array}$ & $\begin{array}{l}\text { Sink. } \\
\text { Urinals. } \\
\text { Toilets, } \\
\text { centrifuges. } \\
\text { wash basins, } \\
\text { shower. } \\
\text { Water mixer. } \\
\text { taps }\end{array}$ & $\begin{array}{l}\text { - Inspect and install all the fulcrums by nails and silicon, } \\
\text { • check and install the points of contact with the drain pipes. } \\
\text { Verification of links and joints. } \\
\text { - Cleansing and repair the siphons. Remove waste from the } \\
\text { sewage. } \\
\text { - Replace all drainage hoses. Ensure that toilets work } \\
\text { properly. } \\
\text { - Inspection of sinks and basins. } \\
\text { - Verification of waste and residues to reduce clogging of } \\
\text { the pipes. }\end{array}$ & 4 \\
\hline \multirow[t]{3}{*}{16} & \multirow[t]{3}{*}{$\begin{array}{l}\text { Sanitatio } \\
\mathrm{n} \text { and } \\
\text { water } \\
\text { supply }\end{array}$} & $\begin{array}{l}\text { galvanized } \\
\text { steel pipes. } \\
\text { Polyethylene } \\
\text { pipes. } \\
\text { Insulation } \\
\text { coatings. } \\
\text { Distribution } \\
\text { network. }\end{array}$ & $\begin{array}{l}\text { - Check and clean up the joints, and fixing the welding. } \\
\text { • Check the water supply systems include the following: } \\
\text { - Check the chlorine remaining in the sample } \\
\text { points (sample check) on a regular basis } \\
\text { from each branch to complete the } \\
\text { verification of the network once in six } \\
\text { months. } \\
\text { Clean the dead ends to the network supply } \\
\text { once every three months, check valves every } \\
\text { six months }\end{array}$ & 6 \\
\hline & & $\begin{array}{l}\text { Valves } \\
\text { Hot galvanized } \\
\text { iron pipe. } \\
\text { Drainage pipes. }\end{array}$ & $\begin{array}{l}\text { - Checking water tanks, basins and sinks. Cleaning pipes } \\
\text { with water to remove sediment. } \\
\text { • Inspect the sewage rooms once a year. } \\
\text { - The plan to paint equipment and connections: } \\
\qquad \quad \text { Paint the water supply fixtures once a year } \\
\text { depending on the rate of corrosion. } \\
\text { Paint the equipment (pumps, motors, pipes } \\
\text { ramifications), by bituminous or industrial } \\
\text { paints. }\end{array}$ & 6 \\
\hline & & $\begin{array}{l}\text { Sewage tanks } \\
\text { and wells. } \\
\text { Sewage pipes, } \\
\text { plastic pipes. } \\
\text { plastic pipes }\end{array}$ & $\begin{array}{l}\text {-Disinfection and cleaning of manholes, including } \\
\text { ventilation holes for wells. Clean horizontal pipe with the } \\
\text { proper tools to remove all dirt and debris. } \\
\text { • Ensure the manhole covers in their place. } \\
\text { - Verify non-clogging the pipes by the waste, and the lack } \\
\text { of leaks. }\end{array}$ & 1 \\
\hline
\end{tabular}




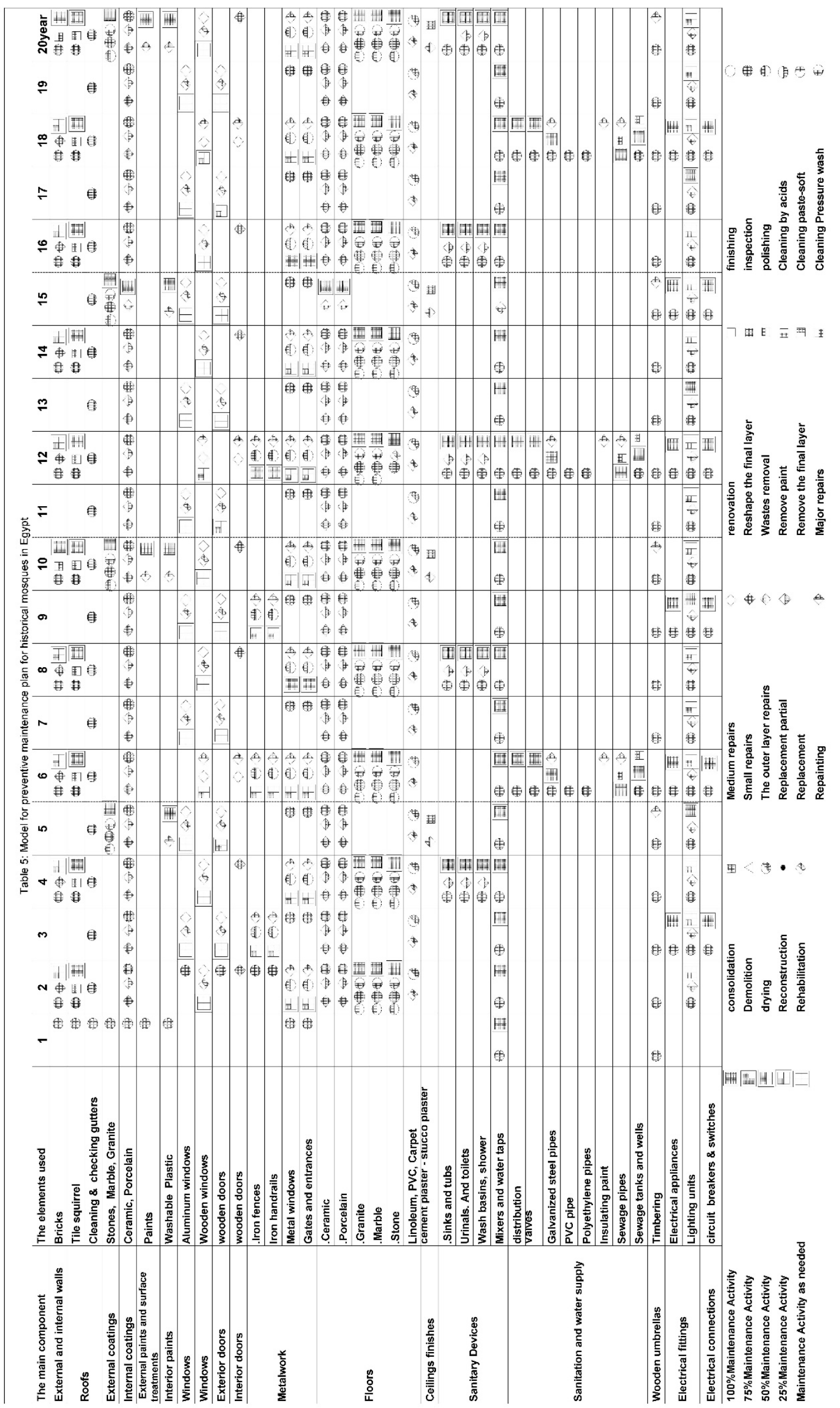




\subsection{Guide to Maintaining Historic Egyptian Mosques:}

Through the previous tables (2), (3), (4), we can formule table (5), which is a guide to maintaing historic Egyptian mosques, by it we can identify the different timing of the inspections.

\section{CONCLUSIONS AND RECOMMENDATIONS:}

This paper found a guide to the maintenance the new elements in the historical mosques dependent on life span studies, including inspection and testing schedules and maintenance operations of the various elements. Failure to follow the maintenance plan in the historic mosques leads to deterioration. Furthermore, a set of challenges and recommendations should be taken into consideration including applying this guide on the historical mosques in Egypt and test it for the dissemination of their results or avoid the negatives. It's also important to Update and evaluate the time plan to inspect the elements of historical mosques based on what appears in the various application stages.

\section{References:}

1- J. Breen, A. Boersma, (2005), "LONG TERM PERFORMANCE OF EXISTING PVC WATER DISTRIBUTION SYSTEMS ", 9th International PVC Conference, Brighton, 26-28 ${ }^{\text {th }}$, pp 307-315, http://www.pvc4pipes.com/images/pdfs/Long-term-performance-ofexisting-PVC-water-distribution-systems.pdf. [Accessed 4-2- 2017]

2- $\quad$ Office of the legislative auditor, (2000), "Preventive Maintenance for Local Government Buildings", State of Minnesota, P 3, Available online at www.auditor.leg.state.mn.us/ped/pedrep/0006all.pdf, [Accessed 26-01- 2017].

3- Panchdhari , A. c. (2007), " Maintenance of buildings ", New Age International limited New Delhi.

4- $\quad$ Spirinckx Carolin \& others, (2011), "Life Cycle Assessment of a PP pipe system for soil and waste removal in the building (according to EN 1451)", Study accomplished under the authority of The European Plastic Pipes and Fittings Association - TEPPFA. www.bureauleiding.nl/.../EPD/PP-Thirdpartyreport-sept2011.pdf [Accessed 4-2- 2017]

5- $\quad$ the Economics Group of NAHB, (2007), "Study of Life Expectancy of Home Components", National Association of Home Builders, Bank of America Home Equity, http://stevesmallman.com/wp-content/uploads/2013/05/NAHB-Lifetimes.pdf. [Accessed 4-2- 2017] 